\title{
Research and Practice on School-Enterprise Collaboration in Distance Education
}

\author{
Xiyu Pang, Cheng Wang \\ Shandong Jiaotong University, Shandong, China \\ Email: xiyupang@126.com,wangcheng_1001@yahoo.com
}

How to cite this paper: Pang, X.Y. and Wang, C. (2017) Research and Practice on School-Enterprise Collaboration in Distance Education. Open Journal of Social Sciences, 5, 209-215. https://doi.org/10.4236/jss.2017.55015

Received: April 6, 2017

Accepted: May 15, 2017

Published: May 18, 2017

Copyright $\odot 2017$ by authors and Scientific Research Publishing Inc. This work is licensed under the Creative Commons Attribution International License (CC BY 4.0).

http://creativecommons.org/licenses/by/4.0/

(c) (i) Open Access

\begin{abstract}
In view of the drawbacks of "Three plus One" model in school-enterprise collaboration, we apply modern distance education in school-enterprise collaboration. This paper points out the problems in this model and its solutions. We put the junior students into practice and make good results.
\end{abstract}

\section{Keywords}

Engineering Competence, “Three Plus One” Model, Modern Distance

Education

\section{Introduction}

Modern distance education has been widespread in China, especially in forward looking higher distance education institutions, and in comprehensive universities, medical universities, correspondence institutes, and radio and television universities. Modern distance education as China's third generation of distance education in our country has to carry out pilot projects for more than ten years, and with a certain scale of its development, social influence is an important part of modern education and lifelong education system, and the teaching methods and means a lot depend on modern information technology.

By the end of August 2004, the national Ministry of Education approved a total of 68 universities to become engaged in modern distance education pilot schools. 68 universities approved in modern distance education pilot, first established specialized teaching, management and technical departments to carry out the distance education in-depth research, and establish a network education teaching and the service mechanism. At the same time, the national ministry of education also encourages university wide cooperation and social institutions, such as TCL, Haier, Lenovo, and the Chinese learning network, such as Sana, distance education institutions and companies have gradually joined the con- 
struction of China Modern Distance Education Pilot Universities. Distance education has achieved fruitful results and experience in this kind of new education form [1] [2] [3] [4].

School-enterprise collaboration has also been applied in higher education institutes in China at present, yet the combination of the distance education and school-enterprise collaboration has seen rare existence in universities in China.

Shandong Jiaotong University is an application-oriented university, and its aim of talents cultivation is to cultivate application-oriented special talents with innovation ability and comprehensive competence. At present, we adopt "Three plus One" talents cultivation model, which has greatly enhanced the students' practical ability, and enabled the students to familiarize with the environment in the enterprises and adjust themselves to their work at an early time.

In "Three plus One" talent cultivation model, students study in the school during the first three years, and during the last one year students practice in the enterprise. This is a very popular talent training mode in Colleges and Universities. However, there are also some problems. In the one year internship in the enterprises, their education in the universities would be hindered. We could not make a balance. In addition, it takes considerable efforts and resources in the training programs at the enterprises in the first period for the students. "Applying modern distance education in school-enterprise collaboration and enhancing the students' practical ability", will on one hand, enhance the students' practical ability, and on the other hand, do not interfere with the study in the university and reduce the costs for the enterprises. This new model adapts to the development of both the university and enterprises. In view of this, taking advantages of modern distance education, Shandong Jiaotong University and Vance Information Co., Ltd. (Beijing) established in-depth experience simulation training model, and cultivated IT talents with practical ability in joint efforts under the guidance of career development [5] [6] [7].

\section{The Application of Modern Distance Education in School-Enterprise Collaboration}

\subsection{Problems to Solve}

Any collaboration is based on the objective of win-win situation. In the case of the application of modern distance education in school-enterprise collaboration, cultivating IT practical talents for the development of enterprises is a win-win strategy of school-enterprise collaboration. For this strategic objective, we should solve the following problems:

a) The content of the collaboration

The core issue of the research and the prerequisite of the practice are to define the schedule of modern distance education and the curriculum, centered on the demand of the enterprises and enhancing the students' practical ability, and preceding from the practical situation.

Shandong Jiaotong University is an undergraduate academy, and its teaching plan is defined in strict accordance with the education system. The problem lies 
in how to take the courses offered by Vance Information Co., Ltd (Beijing) into the teaching plan.

In addition, another issue is that we should launch distance education at which grade. At present, we have two plans: the first one is to launch distance education at the beginning of their study in the university step by step; the second one is to launch distance education in the third year or the fourth year.

It is also of great importance as to offer what courses in modern distance education. In the decision making, we should take the requirements of the enterprises into consideration, but also long term development of the students and the enterprises. Besides, we should avoid overlapping of the content, which will lead to overlapping of resources. The students might have false ideas, and they would deem that distance education has little to do with their study and it might reduce the students' learning motivation.

Vance Information Co., Ltd (Beijing) offers adequate courses:

The first category: basic general courses

By taking basic general courses, the students shall master the basic knowledge and general technique related with their major.

The second category: courses on core technique and computer English

By taking core specialized courses and courses on computer English, the students shall understand and master complete professional technique and enhance their language proficiency.

The third category: courses on enterprise application technology and workplace English

By taking courses on the latest enterprise application technology and workplace English, students can enhance their practical application technology and their language proficiency, familiarize themselves with international environment, and enhance their awareness of the development of the industry and their career.

It is our top priority to take the above factors into consideration and choose proper courses in modern distance education.

b) Management in the collaboration

In order to ensure successful collaboration, besides the teachers, students and hardware conditions, a key factor is the administrator who is responsible for coordination and scheduling. The administrator should work independently and shoulder responsibility. In order to fulfill this target, we should define his ability, professional knowledge, language proficiency, management skills, and the role he plays. We should clearly define these issues and conduct an in-depth research.

c) The examination issues in the collaboration

In order to ensure the quality of the collaboration, there should be a complete examination system. In the making of examination system, we should emphasize the students' subject status, stress the students' value and rights. With the aim for the students' development, we should respect, support, guide and take care of the students. 


\subsection{Our Experience and Primary Practice}

Information Science and Electric Engineering College in Shandong Jiao tong University makes in-depth collaboration with Vance Information Co., Ltd (Beijing) for junior students with the application of modern distance education in the second semester of the academic year of 2010 to 2011. We adopt cosponsored mode with Vance Information. Vance Information is responsible for project operation management and system platform establishment; our college takes charge of the establishment of basic design and coordination with the university.

Students learn basic knowledge and professional theoretical knowledge in the school in the first two and a half years during the university, and from the second semester of the third year of the university, Students according to their own will learn different courses, these courses are set up by the enterprise and the school, and the teaching of the course is carried out in the enterprise by the teachers of the enterprise, and the mode of teaching is based on the mode of Modern Distance Education, the students are organized by the school teachers in the school.

In order to solve management problems, Vance Information Co., Ltd (Beijing) establishes training department, which takes charge of modern distance education program in school-enterprise collaboration. Information Science and Electric Engineering College in Shandong Jiaotong University sets up computer training group based on young teachers, which is responsible for environment building and testing, and the coordination and communication with the enterprises.

In order to take the courses of Vance Information Co., Ltd. (Beijing) into teaching plan, we adopt modern distance education in the form of optional courses and curriculum design in the premise of not interfering regular teaching activity. Optional courses are extended in the university, and curriculum design is a practical teaching link, that is, after taking courses, the students do design practice after taking courses, using their learned knowledge. Generally, the teachers give questions and guidance, and the students make design. The teaching plan of the school ensures that students have enough theoretical knowledge, and they can learn enterprises application technique in the form of optional courses and course design, which cultivates the practical technique and language proficiency of students.

At the beginning of the second semester of the third year, since junior students have taken relevant courses, centered on the target of enhancing the students' practical ability and raise employment rate, Information Science and Electric Engineering College choose two courses as optional courses from the courses offered by Vance Information Co., Ltd: that are, Programming under Linux Environment and Practical Operation, and Preliminary Courses on Android, which are in the charge of experienced teachers in the computer training group. We inform junior students to sign up for these two courses. We make use of modern distance education equipment to give the two optional courses of- 
fered by Vance Information. Experienced engineers give the courses of Vance Information, which makes it possible for the students to get and master the enterprise's professional knowledge in the university. The students can interact with the experienced engineers by modern distance education equipment, through which the students could master the professional knowledge of the enterprise, but also get to know about Vance Information, laying the foundation for their career life.

In the second semester of the third year, in accordance with the school's teaching plan, from the fifth week to the eighth week, we have four weeks of courses on curriculum design of comprehensive project training. In order to cultivate qualified talents for software enterprises, on the morning of curriculum design, we have Vance Information's courses through modern distance education: practical case analysis and software testing. Teachers in Vance Information will give simulation homework, and in the afternoon, the students do their homework under the guidance of the teachers in computer training group. This is well received by the students and bridges the gap between the university and enterprises. The students will get to know how their knowledge is applied in the enterprises, and make their career life in advance, enhance their competitiveness, understand the urgency of learning, which greatly improves the students' practical ability.

In order to guarantee the quality of modern distance education in school-enterprise collaboration, project training department in Vance Information Co., Ltd and computer training group in Shandong Jiaotong University conduct negotiation, and offer an examination system. The plan is as follows:

1) In the middle of each course or course design, we conduct anonymous evaluation of $70 \%$ of the students, which include: course quality, teaching quality, and learning environment and these could be divided into smaller factors. In accordance with the students' evaluation, training department in Vance Information Co., Ltd (Beijing) and computer training group in Shandong Jiaotong University conduct negotiation, talk with the students, get further information and devise solutions.

2) Conduct examination. The lecturer should conduct tests at the end of the optional courses.

The final results obtained from the test scores and grades according to the proportion, the examination is carried through the online examination platform, and the examination are reviewed by the enterprise teacher, and the test scores are given, and the grades are given by the school teachers including: attendance, classroom performance. To curriculum design, at the end of the afternoon of every day the teacher should make evaluation of the students in. This ensures the students' learning motivation and offers supervision.

\section{Conclusions}

In order to promote the further cooperation between universities and enterprises, the paper put forward the method using the distance education into the 
school-enterprise cooperation, and taking Shandong Jiaotong University as the basis, the method has been carried on the practice. Practice has proved that the method can understand the situation of students in the enterprise timely, and the teacher can better supervise and examine the students, therefore the method can deepen the cooperation between school and enterprise, and promote the healthy development of school-enterprise cooperation.

Taking advantages of modern distance education, Shandong Jiaotong University and Information Co., Ltd. (Beijing) Vance (Tong) established in-depth training model, by which the company can save manpower and material resources, but also achieve the purpose of improving students' practical ability through the cooperation between school and enterprise.

Like the traditional "Three plus One" model, students need to practice in the enterprise for one year, and in the time of the year, how to manage students is a big problem such as the student accommodation, safety and so on. The enterprises and the school both need to spend a lot of manpower, material and financial resources, however, this problem can be avoided in this way, and we can achieve the purpose of improving students' practical ability through the cooperation between colleges and enterprises.

Of course, there are some problems in this way: the distance education cannot interact with the students as the traditional classroom education; how to increase the interaction between teachers and students in distance education is a subject worthy of study [8] [9] [10].

\section{Acknowledgements}

Special Subject of Shandong Education Science "12th Five-Year" under Grant No. CBJ15007; China Institute of Communications Education 2016-2018 Annual Education Research Project under Grant No. Communication and research 1602-15; Shandong Jiaotong University Educational Research and Teaching Reform Project under Grant No: JY201509.

\section{References}

[1] Yu, Z.T. (2011) Analysis of the Research Progress in the Field of Distance Education in China from [33] to 2010. 2001-A Quantitative Study Based on CNKI-CAJD Journal Papers. Distance Education in China, No. 7, 24-30.

[2] Chen, Y. (2012) The Evolution of the Main Research Field of Distance Education in China Based on the Analysis of the Key Words of the Distance Education Journal Papers. Distance Education in China, No. 6, 29-34.

[3] Yang, Z. (2011) The Historical Mission of National Open University. China Higher Education, No. 13, 33-35.

[4] Ross, T. (2013) Higher Education: Gaps in Access and Persistence Study. National Center for Education Statistics.

[5] Garcia, J. (2012) Legislative Report on Remedial Education. Colorado Department of Higher Education.

[6] Pang, X. and Wang, C. (2015) Research and Practice on the Cultivation of Engineering Competence for Software Talents in University. Open Journal of Social 
Sciences, 3, 151-154. https://doi.org/10.4236/jss.2015.32020

[7] Rienties, B., Tempelaar, D.T., Dijkstra, J., Rehm, M. and Gijselaers, W.H. (2008) Longitudinal Study of Online Remedial Education Effects. In: Barsky, N.P., Clements, M., Ravn, J. and Smith, K., Eds., Advances in Business Education and Training 1: The Power of Technology for Learning, Springer, Dordrecht, 43-59. https://doi.org/10.1007/978-1-4020-8747-9_3

[8] Zhang, X. (2005) The Combination of Teaching and Learning with the Help of Educational Technology. Technique, 05, 21-23.

[9] Chen, L. (2004) Distance Learning Teaching Interaction Model and Teaching Interaction Level Tower. Distance Education in China, NO. 03S, 24-28.

[10] Fan, R. (2013) Lifelong Learning Hotspot of Distance Education in China under the Concept of Frontier and Analysis on the Development Trend of Audio. Visual Education in China, No. 2, 34-37.

Submit or recommend next manuscript to SCIRP and we will provide best service for you:

Accepting pre-submission inquiries through Email, Facebook, LinkedIn, Twitter, etc. A wide selection of journals (inclusive of 9 subjects, more than 200 journals)

Providing 24-hour high-quality service

User-friendly online submission system

Fair and swift peer-review system

Efficient typesetting and proofreading procedure

Display of the result of downloads and visits, as well as the number of cited articles Maximum dissemination of your research work

Submit your manuscript at: http://papersubmission.scirp.org/

Or contact jss@scirp.org 